\title{
Assessment of Soft Power Strategies: Towards an Aggregative Analytical Model for Country-Focused Case Study Research
}

Artem Patalakh

\section{Abstract}

The paper advances a realist analytical model for case studies of national soft power policies. First, it argues that for the purposes of realist analysis, a soft power policy must be considered as a rational strategy pursued under the conditions of competition. Furthermore, it emphasises the importance of taking into account the specificities of the recipient state as well as the fact that a soft power strategy is targeted at both its elite and its public. In addition, the article substantiates the necessity to draw a clear-cut distinction between soft power sources and instruments and shows possible shortcomings that research can have should this distinction fail to be made. Finally, the paper discusses the impact of a competitor's presence on a soft power strategy and specifies the terms under which disregarding this impact may engender a wrong conclusion.

\section{KEY WORDS:}

realism, soft power, soft power game, soft power instruments, soft power strategy, soft power sources 


\section{Introduction}

Twenty-six years after Joseph Nye (1990) coined the term "soft power" and put forward the respective theory, it seems to have gained great popularity among not only scholars, but also journalists and policymakers. Once designed mostly for describing US policies, it has later been modified in a way that makes it applicable to analysing the foreign policy of practically any state, be it a global or a regional power, or even a small and weak country. The concept's popularity apparently originates from the fact that the information age is fraught with, first, big temptation and, second, many possibilities to influence foreign states through attraction and persuasion rather than coercion, which enables even militarily weak states to be influential.

The spread of the concept has made it popular to do research on the assessment of national policies that aim at ameliorating a country's image in a certain overseas territory.' The most common method in this type of research is a qualitative case study which, as a rule, focuses on why state A needs a good image in country B, how this image is shaped, and what opportunities and workable ways country $A$ has to enhance its reputation in state B. However, without casting any doubt on the deployment of the case study method to the analysis of soft power policies, I argue that the analytical model used in such case studies frequently fails to correspond to their goals and, hence, needs better specification. The main reason for this, to my mind, is that Nye's so-called "agent-centered" approach, where attention is focused primarily on the state that wields soft power, mostly suits the liberal paradigm of IR theory, ${ }^{2}$ the basic premise of which is that countries seek to maximise their absolute gains. For soft power policies, this implies that various countries' peculiarities hardly really matter for country A's strategies toward them, and third parties' role in this process is of minor, if any, significance. In reality, however, as the realist paradigm assumes, many states, especially global and regional powers, are engaged in a geopolitical rivalry, aspiring to maximise their relative gains. For soft power policies, this implies that countries

Since such a "territory" can vary from a region within a country to a macro-region, hereafter, for the sake of simplicity, I refer to it as "country".

2 Joseph Nye himself, however, believes that soft power as a concept is in tune with the realist (Nye 201 1a: 17-18) as well as liberal and constructivist approaches to IR (Nye 2009: 219). 
try to improve their international image not in general, but, rather, relatively to their competitors' image. I argue that in order to study soft power policies through the prism of the realist paradigm, the actual list of the factors to be considered in a case study analysis has to be clarified and extended. By contending this, I endeavour to move forward the ideas of several other scholars who criticise Nye's soft power concept for being too "unstrategic" as an analytical category (Lock 2009) and generally insufficient for a realist analysis of interstate relations (Bilgin and Eliş 2008; Fan 2008).

This paper aims to clarify a "realist" analytical model for country-focused case studies, in which a national soft power policy is deemed a rational strategy under the conditions of interstate competition. I call the model "aggregative", since it embraces features peculiar to three types of actors: the "applicant" (the state that conducts a soft power strategy), the "recipient" (the state a soft power strategy aims at), and competitors (states whose soft power strategies towards the same recipient aim at goals that are contrary to the applicant's ones). The model puts forward three major arguments: 1) the particularities of the recipient as well as the attitudes of both its elite and public must be taken into account; 2) researchers must draw a clear distinction between the applicant's soft power potential (sources) and the means it uses to achieve strategic goals (instruments) and take them both into consideration; 3) the applicant's strategy, where necessary, must be considered in light of the competition with other applicants.

Structurally, the paper follows the logic of the coverage of the abovementioned points. In Section 2, I define a soft power strategy, describe its goals and the actors engaged as well as discuss the importance of considering the recipient's distinctive features - its elite and its public - as units of analysis in case study research. My points are also exemplified by references to papers which, in my opinion, would have benefited from having had my arguments taken into account in their analytical models. Section 3 is focused on the significance of differentiating between the sources and instruments of a soft power strategy. In Section 4, I elaborate on the importance of considering the presence of a competitor for the assessment of the applicant's soft power strategy and specify the conditions under which the factor of competition cannot be omitted in a case study. The final section, Conclusions, summarises the results of the study and proposes possible topics for further analysis. 


\section{Soft Power Strategy: Definition, Goal, and Actors}

Involved

As a concept, soft power has undergone certain changes since it was created. Actually, one can distinguish between at least two interpretations of soft power. In its narrowest understanding, which is in tune with Nye's initial definition (1990), soft power is just the power of attractiveness, a capability to "get others to want what you want" (167) with your good reputation and positive image. However, his latest definition of soft power defines the concept in much broader terms, as "the ability to affect others to obtain preferred outcomes by the co-optive means of framing the agenda, persuasion, and positive attraction" (201 1a: 19). In fact, this re-definition has generated some confusion over the concept among scholars (Fan 2008: 148), even though Nye's personal conception of soft power seems to have always been the same: to influence someone with the use of soft power means to be capable of getting from her what you want without any resort to payment or coercion.

Not only the definition in particular, but even the general idea of soft power has been caviled at due to its arguably limited applicability to analysing national foreign policies. Its critics argue that, first, governments are unable to fully control soft power (Ifantis 2012: 443), second, to predict its efficiency is hard due to local peculiarities in every recipient country (Seiichi 2015: 192), and, third, it appears scarcely possible to measure and quantify it (Xiangping 2016: 307). Even Joseph Nye himself (2011 b: 83) admits that "incorporating soft power into a government strategy" is hard due to three reasons: its outcome is too contingent on the target, to achieve visible results takes a lot of time, and the instruments are not totally controlled by governments. To my mind, however, all this does not mean that the concept of soft power is useless and must be discarded, as some have proposed (see, for example, Hall 2010). In the end, from the viewpoint of common sense, it is, of course, true that nobody can manage what others think of them, but it is equally true that everyone can always do something to improve their reputation, and that is exactly what states try to do in international relations. Nye (2011) himself distinguishes between passive and active approaches to soft power: the former presupposes affecting others "like the light shining from "a city on the hill'", the latter 
implies making "active efforts to create attraction" (94), in other words, conducting a deliberate strategy.

Though a clear definition of soft power strategy has yet to appear in the academic literature, this term has been widely used in the meaning of a coherent and purposeful set of actions aimed to improve a country's image abroad (for examples of the concept's application in leading academic journals, see Lee 2009; Watson 2013; Ogunnubi and OkekeUzodike 2015; Sergunin and Karabeshkin 2015). As previously stated, the state that pursues a soft power strategy can be called "applicant" (Lee 2009: 21 1-212), some authors also call it "sender" (D'Hooghe 2010: 2), "agent" (Hayden 2012: 41; Vyas 2011: 45-48), or "wielder" (Altunişik 2008: 41; Nadkarni 2013: 143), while the country that the strategy aims at is called "recipient" (Sun 2012: 13-14; Lee 2009: 21 1-212; Lee 201 1: 140) or, in other papers, "subject" (Hayden 2012: 41), "receiver" (D'Hooghe 2010: 2), "target" (Nye 2011 b: 84). This distinction, however, lacks academic clarity, since all forms of social power involve a two-way relationship (see Barnett and Duvall 2005), which in practice implies that when the applicant affects the recipient with its soft power, she also gets, in turn, influenced by the soft power of the latter. Therefore, some authors suggest referring to both sides of the soft power interaction as "clients", pointing to the fact that, as distinct from the hard power relationship, where "the target is the passive or unwilling participant", in the case of soft power "both parties are willing participants" (Vuving 2009: 8). To be precise, those authors are right. However, in my opinion, for scientific convenience it is reasonable to differentiate between applicants and recipients in order to avert confusion between the subject and the object of research.

\section{Considering Recipient's Distinctive Features}

My argument in this section is that taking into account the distinctive features of the recipient is indispensable in case studies of the applicant's soft power strategy. Admittedly, this point might sound rather banal; moreover, it has already been, at least partially, suggested by several other scholars (see Lock 2009; Vyas 2011; Kudryavtsev 2014). However, I still put it forward here once again, for it needs better exemplification and specification. 
There are, in my opinion, at least two reasons for taking regional specificities into consideration. First of all, various recipients can perceive the same features of the applicant differently, even when the applicant's soft power strategies toward them are identical. This can also be the case with regard to different regions of the same recipient country, particularly if it includes autonomous areas with various types of minorities. A concrete list of factors that affect a strategy's overall perception in a country or a region includes its ethnic, linguistic and religious composition, its political regime, the applicant-recipient bilateral relations in the past, other social and cultural factors. A good example illustrating the importance of such factors is contemporary Ukraine, where people are highly split over the attitude to the EU and Russia: to illustrate, in 2015, in West Ukraine, $72 \%$ of the citizenry believed that the EU must be Ukraine's main partner and $61 \%$ considered Russia a major threat, while in East Ukraine such views were shared by only $39 \%$ and $30 \%$ of people respectively (Simmons, Stokes and Poushter 2015: 37-41). This difference apparently originates in religion (West Ukrainians are mostly catholic whereas in the East orthodoxy is more widespread), language (in East Ukraine, Russian is more popular than Ukrainian, while in the West it is vice versa), history (in contrast to East Ukraine, the Western part was historically more connected to Poland and Hungary than to Russia) etc. Therefore, the failure to consider regional peculiarities may lead to an erroneous conclusion: a soft power strategy, which is successful in one country, can misfire in a region that differs in its internal conditions. In other words, the reason for a strategy's failure or success can lie in the recipient's specificities rather than the features of the strategy itself.

In addition, applicants themselves tend to adjust their soft power strategies to particular recipients, which can be reflected, first of all, in the intensity of activities: states normally pursue particularly active foreign policies in their neighbourhoods due to having special strategic interests there. Russia, for instance, is particularly active in its "near abroad" (Tarufo 2014: 4), which is even reflected in its Concept of Foreign Policy stating that CIS countries are of utmost strategic importance (MFA of Russia 2013). Poland's most intensive soft power activities centre on Belarus and Ukraine, owing to their cultural and historical proximity as well as the political and economic significance of those states for Poland (Sadowski 2015: 77). 
Besides intensity, regional peculiarities can also have an effect on the content of a strategy. For example, if certain values of the recipient are too contradictory to the applicant's ones, the latter often prefer not to emphasise them greatly, otherwise the whole strategy's success will be put at stake. Critics often call this approach a "double standards" policy and accuse it of being immoral; however, in fact, it reflects a mere rational interest to win "hearts and minds". Examples of such "double standards" abound. The US often expresses serious concern about human rights violations in Iran, but does it less strongly and frequently with regard to Saudi Arabia, its partner in the Middle East. Conservative Russia tends to criticize the EU and the US for promoting LGBT rights, but never does the same when it comes to Brazil and South Africa, its BRICS partners that have also legalized same-sex marriage.

I would also like to cite examples of the papers where regional peculiarities are disregarded, which, to my mind, leads to distorted conclusions. One study, entitled "Limits to Russian soft power in the post-Soviet area" (ĆweikKaprowicz 2012) and dedicated to the shortcomings of the Russian soft power strategy with regards to that territory, describes the Russian policy in the whole post-Soviet area, but assesses its reception only in its East European part, mostly in the Baltic states, Moldova, Ukraine, and Georgia. Naturally, should the author have looked at other countries of the region, like Belarus or Armenia, or the post-Soviet countries of Central Asia, he would have discovered a much warmer perception of the same Russian policies, which probably would have made him admit that the overall soft power of Russia in the region actually has a much greater potential than what his research concludes. Another article, devoted to the Chinese "global" soft power strategy, optimistically concludes that China's "peaceful rise" strategy is so successful that it "has generated an international platform for Beijing to share its opinion on key international issues and garner increased respect on a global scale" (Ding 2010: 271). Even if this is true, and the overall image of China may indeed have improved in the last several years, I believe that the article should at least have mentioned that the regional receptions of China in the world vary noticeably. It especially matters in the case of the Western countries (the US, the EU) as well as a number of China's neighbours (Japan, Vietnam, the Philippines) who view China mostly in negative terms (Pew Research Center 2014: 26-27), which, actually, complicates its "peaceful rise" in strategically important regions. 
Finally, regional specificities are discounted in now popular soft power rankings or indices (see, for example, Ernst \& Young 2012; McClory 2015) designed to estimate national attraction by summing up its main components, the selection of which sometimes appears quite equivocal. For instance, one of them includes "literacy rates" as a compound variable (McClory 2015: 50), which, in my opinion, in the contemporary period, may be topical for some developing countries, but can hardly serve as an indicator of attractiveness among citizens of developed states, where literacy is common and, hence, taken for granted. Another component of soft power in that index is democracy and civil liberties, which seems even more moot: a great part of the world's citizens, especially in Africa, Asia, and the Middle East feel quite indifferent to these values, which becomes apparent in opinion polls (see, for example, Wike and Simmons 2015: 13). In other words, when it comes to attracting particular people, democracy can be of great importance, but considering it to be a universally accepted value seems wishful thinking.

\section{Who Is Affected by Soft Power: Taking Account of Elites and Publics}

As follows from the theory, the main goal of "soft empowerment" is to change the recipient government's preferences in a way favourable for the applicant (Gallarotti 201 1:35-37). In Nye's view, there are two possible ways to achieve this: the applicant either directly affects the recipient's elite, or it attracts the recipient's public, which, in turn, will create such an "enabling or disabling environment" that, in the end, will lead to a preferred elite decision (Nye 201 1b: 94-95). A question that logically arises from the first model is whether or not a decision can be taken by a leader without the consent of the public. Should we assume that it is so, then a process of attraction takes place purely in the form of intergovernmental negotiations; put differently, a soft power strategy is identical to traditional diplomacy. If, contrariwise, we suppose that the consent of the public is generally needed for a political decision to be taken, then soft power strategies must be applied via various means directed at the recipient's public. A quick look at some empirical studies makes it clear that public opinion on foreign policy issues is salient in a limited number of cases -s for example, when it becomes "activated" due to the extreme unpopularity of a particular decision (Powlick 1995), in crisis situations (Knecht and 
Weatherford 2006), in the policy selection stage of foreign policy decisionmaking (Foyle 1999), and in case a foreign policy decision is of particularly extraordinary importance (Goldsmith and Horiuchi 2012). In other situations, public opinion can normally be, irrespectively of a country's political regime, either manipulated or quite easily ignored by leaders. In general, the peculiarity of foreign policy is that citizens normally take much less interest in it than in domestic affairs, which makes it easier for leaders to "shape" public opinion as they need (see, for example, Heith 2004; Jacobs and Burns 2004; Jacobs and Page 2005).

This all has an important implication for case studies: to assess the success of the applicant's soft power strategy, its reception by both the recipient's elite and population must be taken into account. If a soft power strategy, in tune with Nye's understanding of soft power, is to be regarded as seeking a positive image not for its own sake, but for certain political goals, then considering both receivers of soft power, namely foreign leaders and publics (Nye 2008: 107), is crucial. As a matter of fact, dealing with purely the recipient's public can also benefit the applicant in certain ways, such as attracting investors, tourists, students, and workforce from that country, and so forth; however, to achieve a favourable political decision this way generally seems hard and will frequently be impossible.

There are plentiful examples of situations in which, due to the influence of another state's soft power, leaders have taken political decisions that were running counter to public opinion. In some cases, this influence is mainly normative: this happens, for instance, when governments have to take unpopular steps to meet the prerequisites for accession to an international organization or a treaty. For example, in 2014-2015, the leaders of such EU candidates and Eastern Partnership states as Serbia, Ukraine, and Moldova, in order to show their support for European values, allowed gay pride parades to be held and adopted various laws supporting the rights of sexual minorities, though such steps were in a glaring opposition to the views of the conservative majority in those states (for parades, see BBC News 2014; Moldova.org 2014; Tejas 2015; for laws, see, for example, Nichols 2013; Tomkiw 2015). Another illustration of soft power's normative influence is the moratorium on the death penalty in Russia, which the then Russian President Boris Yeltsin imposed in 1996 in order to be able to join the Council of Europe, even though he knew that it would be vehemently opposed by society (BBC News 1999). 
In other cases, the nature of soft power's influence can be different from the normative: authorities can wittingly make an unpopular decision in order to express solidarity with their country's partner if they believe that it is in line with national priorities. For instance, the Czech Republic, Estonia, Hungary, Latvia, Lithuania, Poland, and Slovakia contributed their troops to the coalition forces in Iraq in 2003 and beyond, despite the fact that, as opinion polls were indicating, the majority of their citizens resolutely opposed the involvement in that war (Hummel 2007: 31-32). Reportedly, in most cases, the sending of armed forces to Iraq aimed to generate closer ties with, first, NATO in general, and, second, the US in particular, for that country had been most actively supporting their westernisation in the aftermath of the collapse of the socialist camp (see, for example, New Europe 2003; Carroll 2005).

My argument that attracting the elite is often crucial for the applicant does not, however, signify that it is always sufficient: in certain cases, the applicant's strategy can be shipwrecked if it manages to attract only the recipient's elite but not its public. Failure to attract the recipient's public may, for instance, entail some temporary success, but ruin the strategy's long-term goals. This happened, for example, in November 2013, when Russian President Vladimir Putin promised his Ukrainian counterpart Viktor Yanukovich a significant discount on gas and a $\$ 15$ billion bill to get him not to sign an Association Agreement with the EU, a treaty popular among most Ukrainians (The Economist 2013). However, in the end, Russia failed to extract a long-term positive effect from that move: as early as in February 2014 Yanukovich's regime broke down as a result of antigovernmental protests, and the new Ukrainian government signed the Association Agreement one month later. A similar story happened in the 1970s in American-Iranian relations: the US managed to establish a strong friendship with the Shah and his government, which boosted US-Iranian economic and political cooperation. However, America turned out to be incapable of establishing close ties with Iranian civil society, whose anti-Americanism eventually triggered the 1979 anti-Shah Revolution that completely buried the bilateral friendship (Zanchetta 2009; Wise 2011). In both examples, the soft power applicants enjoyed short-term positive effects as a result of their strategies, while in the long run they, on the contrary, suffered a sizeable deterioration in the bilateral relations with the recipient. 
In other cases, failure to affect the recipient's public may result in a less considerable, but still tangible failure of the applicant's strategy. An illustrative example is the failure of the proposers of same-sex marriage at a public referendum in Slovenia in December 2015. EU officials that supported the idea of legalising gay marriages managed to gain the support of the Slovenian authorities, which had passed a corresponding law in March 2015. However, that law never actually entered into force: some conservative organisations managed to collect a sufficient number of signatures to initiate a referendum on the issue, where the majority of voters voted against same-sex marriages (Heath 2015; Oliveira 2015). To cite another example, in 2005 the project of a European Constitution was widely promoted by EU officials and supported by the elites of the EU member states. Nonetheless, it was quite unexpectedly rejected at the referendums in France and the Netherlands, which revealed a considerable gap between politicians and populations: as the then Prime Minister of the Netherlands Peter Balkenende said, "[t]he idea of Europe has lived for the politicians, but not the Dutch people" (The Guardian 2005).

Nonetheless, for some reasons I believe that researchers must take into account the applicant's ability to attract the elite even in the cases where it is the public who plays a decisive role. First, if the recipient's public favours the decision promoted by the applicant and the elite does not, attracting the latter can fasten remarkably the process of achieving the outcome favoured by the applicant. If affecting the current authorities of the recipient is not possible due to, for instance, their strong obstinacy, it can also be reasonable to establish close links with the political opposition, especially if the incumbent government is weak and likely to lose the impending elections. If, for instance, the above-cited case of the 2014 Ukrainian revolution is to be considered from the perspective of the EU, its success in enlisting the support of the Ukrainian opposition leaders made it possible to get the Association Agreement signed already in March 2014, which the EU had been seeking for several years.

Second, whereas civil society may indeed impede the taking of certain particular decisions, general policies are still normally in the hands of the government. Therefore, should the recipient's elite favour a certain soft power applicant, the overall policies of the former will most probably be in line with its wants. For instance, although the Slovenian government, as 
I mentioned before, failed to legalise same-sex marriage, as promoted by the EU, through a referendum due to the reluctance of the country's citizenry, it still managed to take numerous other measures to promote tolerance toward gay people (see University of Toronto 2014). To give another example, the Berlusconi government of Italy, wary of public resistance, decided to not send ground troops to Afghanistan to support the US-led anti-terrorist operation in 2001-2002; however, it backed its ally in many other ways, including providing some military assistance (Davidson 2009: 301).

Unfortunately, academic papers often neglect the elite dimension of soft power strategies, which leads to incomplete or even distorted conclusions. For instance, in her research on Russia's soft power strategy in Crimea in the 2000s, Roslycky (2011) took account of its various local "conductors" and receivers, considered the attitude of Ukraine's central government to Russian activities on the peninsula, but failed to take cognizance of the role of the local Crimean elite and authorities. Nevertheless, as subsequent events showed, it was the Crimean elite's support of Russia that played a decisive role in the 2014 annexation of the peninsula: hardly any Crimean politician tried to protest against it, which made it extremely easy for Russia to carry out the occupation. After the annexation, most of the Crimean elite remained in the government simply by changing their membership from Ukraine's pro-Russian "Party of Regions" to Russia's ruling "United Russia" party.

Another example is Sadowski's (2015) study of Poland's soft power strategy in Eastern Europe, in which he draws attention to the importance of Belarus and Ukraine for Poland's soft power activities: "Poland is far more active in Ukraine and Belarus than in Moldova and Georgia. Cultural and historical proximity, and political and economic importance, are important factors influencing the higher level of engagement in Ukraine and Belarus" (ibid: 77). In his opinion, it is Poland's soft power activities that explain the positive image of Poles among Ukrainians and Belarusians, which becomes apparent in opinion polls. Later, he also maintains that Ukraine shows a substantial interest in using the Polish experience of reforms and transition, but does not mention anything similar in relation to Belarus (ibid: 78). A logical question that arises is why, even though Poland is active in both countries and both nations feel positive about the Poles, only Ukraine 
cooperates with Poland politically? Much of the answer seems to lie in the fact that Poland, focusing on Belarusian civil society as a receiver of its soft power strategy, pays insufficient attention to Belarus' elite, which is known to be pro-Russian and, thus, quite unamicable to Poland, Russia's strong opponent.

\section{Sources and Instruments of Soft Power}

Similarly to any kind of a purposeful action, a soft power strategy has its sources and instruments (or means) through which it can be achieved. Soft power sources, ${ }^{3}$ as follows from a narrow understanding of soft power, are a country's distinctive features that generate attraction. The problem of defining a concrete list of sources has been extensively debated in the academic literature and lies beyond the scope of this article (for a discussion, see, for instance, Fan 2008; Vuving 2009; Hall 2010; Nye 2011 b), but the most commonly applied in country-focused case studies are the ones proposed by Nye (2004): a country's "culture (in places where it is attractive to others), its political values (when it lives up to them at home and abroad), and its foreign policies (when others see them as legitimate and having moral authority)" (11). A soft power strategy's instruments are mechanisms through which an applicant transmits the influential capacity of its sources to the receivers, i.e. the elite and the public of a recipient country. Nye, for instance (201 l b), singles out four main channels through which states can use their soft power, notably "public diplomacy, broadcasting, exchanges, and assistance"4 (94).

It is noteworthy that in Nye's theory the distinction between the two is somewhat elusive: while there is a clear logical discrimination between sources and instruments, sometimes they coincide, which is deemed to be a weak point of Nye's theory. In his above-mentioned "culture, values,

3 I deliberately do not use the word "strategy" in the definition, since obviously there is no difference between "sources of soft power" and "sources of a soft power strategy": whether or not soft power affects the recipient with or without a state-led rational strategy, it has the same foundations.

4 Importantly, these lists of sources and instruments are not exhaustive: in the end, a any feature of a country can serve as a source of hard or soft power depending if it is used in a coercive or co-optive way. For instance, culture can be a source of hard power if it is aggressively imposed rather than peacefully promoted. And military forces can produce soft power if they are used to keep peace (for details, see Nye 2011 b). 
foreign policy" triad, with respect to what concerns values the distinction is clear: they are a source that is promoted by an applicant through broadcasting and various public diplomacy programs. However, as for foreign policy, Nye's interpretation seems to be semi-tautological: "other actors will support an attractive foreign policy, the attractiveness of which is defined by the degree to which other actors support it" (Hall 2010: 204). Put differently, foreign policy represents a collision of a soft power strategy's sources, instruments, and even goals, which has engendered some criticism of Nye's approach.

Despite such occasional overlaps, my argument is that, in case study research, where possible, it is preferable to, first, clearly differentiate between sources and instruments, and, second, consider both aspects. First of all, this is obviously conducive to the comprehensiveness of the analysis: so as to find out how and why a certain goal has (not) been achieved, it is logical to first estimate the applicant's potential, and then analyse the ways it was meant to be translated into the outcome. However, incompleteness is only one of the possible negative consequences to which omitting sources or instruments in a case study may lead. What is more important, this can result in a faulty conclusion in the following several ways.

The first common flaw of country-focused case studies is to consider merely the sources of soft power for the assessment of its effectiveness. Authors doing so fail to treat soft power as a rational strategy and, hence, link the applicant's (un-)popularity solely to its soft power sources, which can bring about two central misconceptions. First, if a country does not possess many sources, it does not necessarily mean that it cannot be popular anywhere: a strategic approach shows that a country can be "powerful" in a "soft" way even if it does not possess many sources, but wisely uses the ones it disposes of. The examples of such cases are the use of animé and manga by Japan in the absence of a popular foreign policy (Lam 2007: 350), the application of the rhetoric of anti-Americanism by Russia in the absence of popular values (Trilupaityte 2008), and so forth. Conversely, if a certain country is unpopular somewhere, it is not necessarily caused by the imperfections or shortage of its soft power sources: the answer, again, may lie in how wise a country disposes of its soft power potential. India, in the opinions of some scholars, has great soft power potential, but its 
international image is hampered by the fact that it does not undertake sufficient and adequate measures to promote it (Mukherjee 2014: 48-49).

This argument is in concordance with a broader approach in political science, which posits that power should preferably be measured in terms of outcomes rather than resources (Hart 1976; Gallarotti 2011: 41). At the same time, a number of scholars contend that in certain cases a resource-based assessment of power can also be useful; for example, when it comes to policy-makers making forecasts: "in general, a country that is well endowed with power resources is more likely to affect a weaker country and be less dependent upon an optimal strategy than vice versa" (Nye 2011 a: 12). However, although I agree that there is a grain of truth in this reasoning, I still believe that a resource-based approach is more suitable for policy-makers who have to make decisions immediately, but not academic researchers who normally have enough time to analyse an issue thoroughly. Also, I believe that a resource-based approach is more applicable to hard power, as it is easier to quantify its resources, while in the case of soft power there is no objective scale to use in assessing it, which can often lead to the overvaluation or underestimation of the applicant's potential.

On the contrary, treating a country's popularity merely as a function of its soft power instruments - in other words, equating soft power with the measures a state takes to promote itself and disregard its potential to do so - is equally questionable. On the one hand, such an approach to soft power displays strategic thinking in terms of purposeful behaviour, which is certainly good. However, this vision contradicts a rule of sales theory, according to which a good product does not need much advertising and a bad product will not sell no matter how hard it is promoted. As Anholt (2009) fairly argues, "Many countries have wasted enormous sums of public money on communications campaigns, based on the assumption that people don't respect their country simply because they don't know enough about it. In most cases, they are deluding themselves, and the real reason why their country has a negative reputation is that it doesn' $t$ deserve a positive one" (90). Consequently, omitting soft power sources in a case study is fraught with the possibility that a researcher will ascribe a country's good (or bad) reputation solely to its actions, while in fact it can be rooted in its soft power sources. 


\section{( The Factor of Competition}

While the aforementioned points, although undertheorized, are frequently, at least subconsciously, "implied" in case studies, the applicant's competitors are a factor which fails to be considered far more commonly, notwithstanding the fact that in certain cases it is of critical importance for the evaluation of a soft power strategy. My general argument here is that sometimes the way in which a soft power strategy is carried out is highly influenced by the fact of the presence (or absence) of some competing country. There are two main aspects that it affects. First, a competitor has an impact on the level of intensity of the applicant's activities: a feeling that its rival can get ahead in a certain territory can motivate the applicant to put more efforts into promoting its image there. In practice, it can be reflected in increasing the quantity of some type of resources: allocating more money, engaging more people, paying more attention to media coverage, etc. Second, the existence of a competitor can make the applicant alter the content of its activities toward the recipient in an original way by resorting to steps it does not use in other countries. In the summer of 2015, for instance, the EU discussed the need to create a special TV channel to counter Russian propaganda in Eastern European countries, where it is particularly strong (Jozwiak 2015).

Naturally, most soft power strategies exist in a sort of competition: indeed, if a country decides to intentionally cope with its image somewhere, in many cases it is due to the existence of some forces that aim to worsen it. Nonetheless, it does not mean that country-focused case studies must take any competitor into account: rather, they should consider only those competitors who seem to have a chance to seriously affect the applicant's soft power. Such "seriousness", of course, differs from one case to another; however, there are several conditions, the presence of which, to my mind, signalises a researcher that the factor of competition between applicants must be necessarily considered in the analysis.

First of all, the principle of geographical proximity appears significant: the closer a competitor is to the recipient, the more it has to be taken in account in the analysis. The importance of proximity is mostly determined by the fact that soft power applicants tend to treat their neighbours as 
territories of special concern and strategic influence, which is even often reflected in their official documents and the speeches of their leaders. For example, Brazil's top priority, in general and in terms of soft power, is South Africa (Latin American Herald Tribune 2011) and the main direction of Russian foreign policy is CIS countries (MFA of Russia 2013). Also, proximity simplifies the use of soft power instruments from a practical point of view: it dramatically reduces transportation and other transaction costs, ensures a high level of familiarity among the citizens of two countries, etc.

The second factor that makes a competitor an important influencer on a soft power strategy is the presence of an influential group inside the recipient state that supports that competitor. Depending on the country, that group can be an opposition party, a secessionist movement, a religious movement, a financial group, etc. "Influential" in this case simply implies possessing enough power, will, and resources to aid the competitor in achieving its goals. To cite an example, in the on-going EU-Russia geopolitical rivalry in Moldova, both applicants have weighty supporters inside the country: the EU enjoys the support of the incumbent pro-European coalition, while Russia relies upon its close ties with the breakaway region of Transnistria and the Gagauz Autonomous Region (Dempsey 2014). A similar, but somewhat less illustrative of this point, is the competition between China and Japan/the US in Taiwan, where the former enjoys the support of the Kuomintang party while the latter side is backed by the Democratic Progressive Party (Lin 2016). Due to this, hardly any study of the EU's or Russia's soft power in Moldova as well as China's or the US' soft power in Taiwan can be comprehensive if it fails to consider the factor of the competing side's presence.

Finally, there exists one more factor that determines the importance of a competitor for the result of a soft power strategy: the receivers (the recipient's population and elite) must preferably view the situation as a strict choice between two applicants, as a zero-sum game with little or no possibility of a win-win outcome. The applicants, in turn, must have divergent goals, otherwise the whole situation can, at a deeper look, turn out not to be a real competition, but, rather, a minor disagreement between the applicants over technical issues, with their goals being similar. In such cases, even though there may be heated debates between the applicants, a compromise is, in fact, frequently more than possible. For 
instance, at the 2008 NATO Summit in Bucharest the German and US delegations argued over offering membership action plans to Ukraine and Georgia: George Bush was insisting on it, while Angela Merkel was arguing that they were not stable enough to be granted membership action plans, so she proposed not to go beyond close military cooperation between NATO and those countries. Despite the heatedness of their argument, which was about to grow into a big scandal, a compromise was eventually found: both Georgia and Ukraine were promised membership in the future, which was pointed out in the final communiqué of the summit, but the date of their invitation to the alliance was not indicated (Myers and Bowley 2008). In this example, first, the recipients were considering both Germany and the US to be friendly actors, since at that time the goal of both the Ukrainian and Georgian governments was to get closer to the West in order to be protected from Russia, which in order to achieve they were reliant on both European and American aid. Second, the goals of both applicants - Germany and the US - were also very similar, only their methods differed. So, any case studies on the soft power strategies of one of these two applicants with respect to Georgia or Ukraine during that period may omit considering the impact of the other applicant's soft power, since it did not significantly affect the outcome.

It can also be possible that only the applicants view a certain situation as a competition, while the receivers do not consider it a strict choice between two options and want to take advantage of the cooperation with both applicants. In such cases, a situation can be initially deemed as a potential competition rather than an actual one; nonetheless, it can be transformed into an actual one if the receivers change their minds. Sometimes this happens with an intervention of hard power. For instance, in the beginning of the 2010s the EU proposed Ukraine conclude an association agreement and, at the same time, Russia also invited Ukraine to join the Customs Union of Russia, Belarus, and Kazakhstan. At first, Ukraine tried to find a way to take advantage of both integration groups (Buckley 2012); however, later both applicants objected to this policy, forcing Ukraine to make a strict choice. Originally, Ukraine deliberately chose the EU, but, as it was getting ready to sign the association agreement Russia started to apply its hard power tools widely, such as threats to impose sanctions, intervene militarily (Walker 2013) as well as blatant bribery (McElroy 2013), which finally made Ukraine stop its EU integration attempts: 
in November 2013, its Premier Mykola Azarov suspended the signing of the agreement. In this example, the EU-Russian rivalry in Ukraine was, in fact, in its "passive" phase until all its participants, including the recipient, began to view the situation in competitive terms.

\section{Conclusion: The Use and Limitations of the Aggregative Model}

Once again, the proposed framework, especially with respect to what concerns its "competition" and "elite" components, is useful mainly for studies that aim to analyse soft power as a tool of realpolitik. In practice, this implies that the model is hardly applicable to states that do not really pursue political goals in their strategies, instead seeking to improve their overseas image for other ends, like attracting investments, tourists, etc. Another limitation of the model is that it presupposes a rivalry between two or more countries in a third country, supposing that the applicant either does not, in turn, get affected by the recipient's soft power, or gets affected so insignificantly that this impact can be left out. In other words, the framework is not apt for analysing mutual soft power competitions between applicants (situations in which one applicant is simultaneously the recipient of its opponent's strategy), since it requires a complicated analysis of government-opposition and elite-public relations, which moves the study away from the International Relations field.

The paper leaves several questions for future research. The role of competitors, to my mind, must be better tested on case studies and, if it turns out to be possible, we may come up with a theory of "soft power games," that is, interstate rivalries where only "soft" methods, such as attraction, persuasion or framing the agenda, are used. Once defined, soft power games will have to be characterized: we will need a typology of soft power games, their main characteristics and conditions. Another question concerns the limitations of the "strategic" approach to soft power: government-led strategies, as many authors maintain, are not

5 In fact, this term already appears in academic literature and newspapers, but is mostly used as a figurative collocation rather than an academic term (see, for example, Lee 2010: 11; Rengma 2012; Van Herpen 2016: 28) 
( able to achieve everything - much of national image originates in the activities of its civil society and private sector as well as culture, history, national character and other conditions (see, for instance, Nye 2013). However impossible it may seem to separate the government and non-government "contributions" to a country's overseas image, such an assessment (at least a rough one) must be done in order to find out to what extent a national image as such is manageable with rational governmental strategies. 


\section{Bibliography}

Altunişik, M., 2008. The possibilities and limits of Turkey's soft power in the Middle East. Insight Turkey, 10(2): 41-54.

Anholt, S.. 2009. Nation "branding": propaganda or statecraft? PD, 2: 88-90.

Barnett, M. and Duvall, R., 2005. Power in international relations. International Organization, 59: 39-75.

BBC News, 1999. Yeltsin pardons death row inmates, [online] 3 June. Available at: http://news.bbc.co.uk/2/hi/europe/360100.stm [accessed 4 February 2016].

BBC News, 2014. Serbia gay pride march returns after four years, [online] 28 September. Available at: http://www.bbc.com/news/worldeurope-29399404 [accessed 4 February 2016].

Bilgin, P. and Eliş, B., 2008. Hard power, soft power: toward a more realistic power analysis. Insight Turkey, 10 (2): 5-20.

Buckley, N., 2012. Mykola Azarov: Good relations with EU and CIS are 'vital'. Financial Times, [online] 17 September. Available at: http:// www.ft.com/cms/s/0/4f7cld42-f8df-1 1e1-8d92-00144feabdc0. html\#axzz3wxQaO8c2 [accessed 11 February 2016].

Carroll, R., 2005. Estonian troops relish Iraqi patrols. The Guardian, [online] 3 September. Available at: http://www.theguardian.com/ world/2005/sep/03/iraq.rorycarroll [accessed 4 February 2016].

Culligan, K., Dubber, J. and Lotten, M., 2014. As Others See Us: Culture, Attraction and Soft Power. London: British Council.

Ćweik-Kaprowicz, J., 2012. Limits to Russian Soft Power in the Post-Soviet Area. Berlin: DGAP.

D'Hooghe, I., 2010. The Limits of China's Soft Power in Europe: Beijing's Public Diplomacy Puzzle. The Hague: Clingendael.

Davidson, J. W., 2009. Italy-US relations since the end of the Cold War: prestige, peace, and the transatlantic balance. Bulletin of Italian Politics, 1 (2): 289-308. 
Dempsey, J., 2014. Moldova is next battleground for Russia and EU. The Moscow Times, [online] 4 December. Available at: http:// www.themoscowtimes.com/opinion/article/moldova-is-nextbattleground-for-russia-and-eu/512583.html [accessed 12 February $2016]$.

Ding, S., 2010. Analyzing rising power from the perspective of soft power: a new look at China's rise to the status quo power. Journal of Contemporary China, 19(64): 255-272.

Ernst \& Young, 2012. Rapid-growth markets soft power index. Available at: http://www.ey.com/Publication/vwLUAssets/Rapid-growth_ markets:_Soft_power_index/\$FILE/Rapid-growth_markets-Soft_ Power_Index-Spring_2012.pdf [accessed 12 February 2016].

Fan, Y., 2008. Soft power: power of attraction or confusion? Place Branding and Public Diplomacy, 4(2): 147-158.

Foyle, D. C., 1999. Counting the Public In: Presidents, Public Opinion, and Foreign Policy. New York: Columbia University Press.

Gallarotti, G. M., 2011. Soft power: what it is, why it's important, and the conditions for its effective use. Journal of Political Power, 4(1): 25-47.

Goldsmith, B. E. and Horiuchi, Y., 2012. In search of Soft power: does foreign Public opinion matter for U.S. foreign policy? World Politics, 64(3): 555-585.

Hall, T., 2010. An unclear attraction: a critical examination of soft power as an analytical category. The Chinese Journal of International Politics, 3: 189-211.

Hart, J., 1976. Three approaches to the measurement of power in international relations. International Organization, 30(2): 298-305.

Hayden, C., 2012. The Rhetoric of Soft Power: Public Diplomacy in International Relations. Plymouth: Lexington Books.

Heath, R., 2015. Slovenia launches vote on gay marriage. Politico, [online] 15 December. Available at: http://www.politico.eu/article/ slovenia-launches-vote-on-gay-marriage-violeta-bulc/ [accessed 4 February 2016]. 
Heith, D. J., 2004. Polling to Govern: Public Opinion and Presidential Leadership. Stanford, CA: Stanford University Press.

Hummel, H., 2007. A Survey of Involvement of 15 European States in the Iraq War 2003. Düsseldorf: Paks.

Ifantis, K., 2012. Soft power: overcoming the limits of the concept. In McKercher, B. J. C., ed. Routledge Handbook of Diplomacy and Statecraft. Abingdon, Oxon: Routledge, pp. 441-452.

Jacobs, L. R. and Burns, M., 2004. The second face of the public presidency: presidential polling and the shift from policy to personality polling. Presidential Studies Quarterly, 34(3): 536-556.

Jacobs, L. R. and Page B. I., 2005. Who influences U.S. foreign policy? American Political Science Review, 99(1): 107-123.

Jozwiak, R., 2015. EU to counter Russian propaganda by promoting 'European values'. The Guardian [online], 25 June. Available at: http://mww.theguardian.com/world/2015/jun/25/eu-russia-propagandaukraine [accessed 8 February 2016].

Knecht, T. and Weatherford, M. S., 2006. Public opinion and foreign policy: the stages of presidential decision making. International Studies Quarterly, 50: 705-727.

Kudryavtsev, A., 2014. A Systemic View of the Soft Power. Florence: EUI, RCSAS.

Lam, P. E., 2007. Japan's quest for "soft power": attraction and limitation. East Asia, 24: 349-363.

Lang, K.-O., 2015. Germany, the European Union, and their gentle force in the European neighbourhood - a comparison of two soft power engines. In Rostoks, T. and Spruds, A., eds. The Different Faces of "Soft Power": The Baltic States and Eastern Neighbourhood Between Russia and the EU. Riga: Latvian Institute of International Affairs, pp. 30-62.

Latin American Herald Tribune, 2011. Rouseff: South America is priority for Brazil's foreign policy, [online] 25 April. Available at: http:// www.laht.com/article.asp? Articleld=392069\& Categoryld $=14090$ [accessed 12 February 016]. 
Lee, G., 2009. A theory of soft power and Korea's soft power strategy. Korean Journal of Defense Analysis, 21 (2): 205-218.

Lee, G., 2010. China's Soft Power and Changing Balance of Power in East Asia. Paper presented at the Center for US-Korea policy workshop, Seoul.

Lee, S. J., 2011 . South Korean soft power and how South Korea views the soft power of others. In Lee, S. J. and Melissen, J., eds. Public Diplomacy and Soft Power in East Asia. New York: Palgrave Macmillan, pp. 139-162.

Lin, W., 2016. Taiwan Enters the Tsai Ing-Wen Era and the Impact on CrossStrait Relations. Milan: ISPI.

Lock, E., 2009. Soft power and strategy: developing a "strategic" conception of power. In Parmar, I. and Cox, M., eds. Soft Power and US Foreign Policy: Theoretical, Historical, and Contemporary Perspectives. Abingdon, Oxon: Routledge, pp. 32-50.

McElroy, D., 2013. Ukraine receives half price gas and \$15 billion to stick with Russia. The Guardian, [online] 17 December. Available at: http:// www.telegraph.co.uk/news/worldnews/europe/ukraine/10523225/ Ukraine-receives-half-price-gas-and-15-billion-to-stick-with-Russia. html [accessed 12 February 2016].

McClory, J., 2015. The Soft Power 30: A Global Ranking of Soft Power. London: Portland.

MFA of Russia, 2013. Concept of the foreign policy of the Russian Federation. Available at: http://en.mid.ru/en/web/guest/foreign_ policy/official_documents/-/asset_publisher/CptICkB6BZ29/ content/id/122186 [accessed 11 February 2016].

Michalski, A., 2005. The EU as a soft power: the force of persuasion. In Melissen, J., ed. The New Public Diplomacy: Soft Power in International Relations. Basingstoke: Palgrave Macmillan, pp. 124-144.

Moldova.org, 2014. LGBT Activists to organize pride parade in Moldova, [online] 16 May. Available at: http://www.moldova.org/lgbt-activistsorganize-pride-parade-moldova/ [accessed 4 February 2016]. 
Mukherjee, R., 2014. The false promise of India's soft power. Geopolitics, History, and International Relations, 6(1): 46-62.

Myers, S. L. and Bowley, G., 2008. Bush wins NATO backing on shield, but not on Ukraine and Georgia. New York Times, [online] 3 April. Available at: http://wnw.nytimes.com/2008/04/03/world/europe/03iht3shield.11650130.html?_r=0 [accessed 12 February 2016].

Nadkarni, V., 2013. India - an aspiring global power. In Nadkarni, V. and Noonan, N. C., eds. Emerging Power in a Comparative Perspective: The Political and Economic Rise of the BRICS Countries. New York: Bloomsbury Academic, pp. 131-162.

New Europe, 2003. Latvia cannot remain observer in Iraq conflict, Kalniete says, [online] 8 February. Available at: http://neurope.eu/ article/latvia-cannot-remain-observer-iraq-conflict-kalniete-says/ [accessed 4 February 2016].

Nichols, J. M., 2013. Moldova overturns 'gay propaganda' ban in anticipated EU membership move. The Huffington Post, [online] 14 October. Available at: http://www.huffingtonpost.com/2013/10/14/moldovagay-propoganda_n_4096947.html [accessed 4 February 2016].

Nye, J. S. Jr., 1990. Soft power. Foreign Policy, 80(Fall): 153-171.

Nye, J. S. Jr., 2008. Public diplomacy and soft power. The ANNALS of the American Academy of Political and Social Science, 616: 94-109.

Nye, J. S. Jr., 2009. Responding to my critics and concluding thoughts. In Parmar, I. and Cox, M., eds. Soft Power and US Foreign Policy: Theoretical, Historical, and Contemporary Perspectives. New York: Routledge, pp. 215-227.

Nye, J. S. Jr., 2011 a. Power and foreign policy. Journal of Political Power, 4(1): 9-24.

Nye, J. S. Jr., 201 1b. The Future of Power. New York: Public Affairs.

Nye, J. S. Jr., 2013. What China and Russia don't get about soft power. Foreign Policy, [Online] 29 April. Available at: http://foreignpolicy. com/2013/04/29/what-china-and-russia-dont-get-about-softpower/ [accessed 12 February 2016]. 
Ogunnubi, O. and Okeke-Uzodike, U., 2015. South Africa's foreign policy and the strategy of soft power. South African Journal of International Affairs, 22 (1): 23-41.

Oliveira, I., 2015. Slovenia says no to gay marriage. Politico, [online] 20 December. Available at: http://www.politico.eu/article/sloveniasays-no-to-gay-marriage-lgbt-lgbti-rights/ [accessed 4 February 2016].

Peters, I. and Bittner, J., 2006. EU - US Risk Policy in the European Neighbourhood: The Cases of Moldova and Georgia. Paper presented at the ISA Annual Conference, San Francisco.

Pew Research Center, 2014. Global opposition to U.S. surveillance and drones, but limited harm to America's image, [online] 14 July. Available at: http://www.pewglobal.org/files/2014/07/2014-07-14Balance-of-Power.pdf [accessed 11 February 2016].

Powlick, P., 1995. The sources of public opinion for American foreign Policy officials. International Studies Quarterly, 39: 427-451.

Rengma, E. K., 2012. Soft Power Game: A Study of China, India and South Asian Association for Regional Cooperation (SAARC) Tripartite. Paper presented at Emerging Scholars Symposium of India China Institute, New York.

Roslycky, L. L., 2011 . Russia's smart power in Crimea: sowing the seeds of trust. Southeast European and Black Sea Studies, 11 (3): 299-316.

Sadowski, R., 2015. Poland's soft power in Eastern Europe. In Rostoks, T. and Spruds, A., eds. The Different Faces of "Soft Power": The Baltic States and Eastern Neighbourhood between Russia and the EU. Riga: Latvian Institute of International Affairs, pp. 64-79.

Seiichi, K., 2015. Wielding soft power: The key stages of transmission and reception. In Watanabe, Y. and McConnell, D. L., eds. Soft Power Superpowers: Cultural and National Assets of Japan and the United States. Abingdon, Oxon: Routledge, pp. 191-206.

Sergunin, A. and Karabeshkin, L., 2015. Understanding Russia's soft power strategy. Politics, 35(3-4): 347-363. 
Simmons, K., Stokes, B. and Poushter, J., 2015. NATO publics blame Russia for Ukrainian crisis, but reluctant to provide military aid. Pew Research Center, [online] 10 June. Available at: http://www.pewglobal.org/ files/2015/06/Pew-Research-Center-Russia-Ukraine-Report-FINALJune-10-2015.pdf [accessed 14 February 2016].

Sun, J., 2012. Japan and China as Charm Rivals: Soft Power in Regional Diplomacy. Ann Arbor, Michigan: University of Michigan Press.

Tarufo, E., 2014. Fatal Attraction? Russia's Soft Power in Its Neighbourhood. Madrid: Fride.

Tejas, A., 2015. Ukraine gay pride parade attacked with stones, smoke bombs. International Business Times, [online] 6 June. Available at: http://www.ibtimes.com/ukraine-gay-pride-parade-attackedstones-smoke-bombs-1955426 [accessed 4 February 2016].

The Guardian, 2005. Dutch say 'devastating no' to EU constitution, [online] 2 June. Available at: http://www.theguardian.com/world/2005/ jun/02/eu.politics [accessed 4 February 2016].

Tomkiw, L., 2015. Ukraine same-sex marriage law? Bill bans anti-gay discrimination, paving way to visa-free EU travel. International Business Times, [online] 11 December. Available at: http://www. ibtimes.com/ukraine-same-sex-marriage-law-bill-bans-anti-gaydiscrimination-paving-way-visa-free-2181461 [accessed 4 February 2016].

Trilupaityte, S., 2008. Culture or power politics? Post-Cold War antiAmericanism in Russia. In Higgott, R., Malbašić, I., eds. The Political Consequences of Anti-Americanism. Abingdon, Oxon: Routledge, pp. 74-90.

University of Toronto, 2014. Slovenia: country report for use in refugee claims based on persecution relating to sexual orientation and gender identity. Available at: http://ihrp.law.utoronto.ca/utflfile/ count/media/Slovenia\%202014\%20FINAL.pdf [accessed 5 February 2016].

Van Herpen, M. H., 2016. Putin's Propaganda Machine: Soft Power and Russian Foreign Policy. Lanham, Maryland: Rowman \& Littlefield. 
Vuving, A., 2009. How Soft Power Works? Paper Presented at the annual meeting of the American Political Science Association, Toronto.

Vyas, U., 2011 . Soft Power in Japan-China Relations: State, Sub-State, and Non-State Relations. Abingdon, Oxon: Routledge.

Walker, Sh., 2013. Ukraine's EU trade deal will be catastrophic, says Russia. The Guardian, [online] 22 September. Available at: http://www. theguardian.com/world/2013/sep/22/ukraine-european-uniontrade-russia [accessed 12 February 2016].

Watson, I., 2013. South Korea's state-led soft power strategies: limits on inter-Korean relations. Asian Journal of Political Science, 20(3): 304325.

Wike, R. and Simmons, K., 2015. Global support for principle of free expression, but opposition to some forms of speech. Pew Research Center, [online] 18 November. Available at: http://www.pewglobal. org/files/2015/1 1/Pew-Research-Center-Democracy-Report-FINALNovember-18-2015.pdf [accessed 13 February 2016].

Wise, K., 201 1. Islamic Revolution of 1979: the downfall of American-Iranian relations. Legacy 11 (1), article 2.

Xiangping, L., 2016. A new understanding of "soft power". In Keping, Y., ed. On China's Cultural Transformation. Leiden: Brill, pp 295-315.

Zanchetta, B., 2009. The United States and the "Loss" of Iran. Geneva: Graduate Institute of International and Development Studies.

Artem Patalakh (artem.patalakh@unimi.it) is a PhD candidate in Political Studies at Università degli Studi di Milano (Milan, Italy). His research interests include International Relations theory, Russian and EU foreign policies, soft power, promotion of ideas of values in International Relations. He holds BA and MA degrees in Regional Studies from MGIMO-University (Moscow, Russia). 